\title{
Faktor-Faktor yang Mempengaruhi Kualitas Pembiayaan: Persepsi Pegawai BNI Syariah Semarang
}

\author{
Ika Arista ${ }^{1}$, Prabowo Yudo Jayanto ${ }^{2}$ \\ Jurusan Akuntansi, Fakultas Ekonomi, Universitas Negeri Semarang, Indonesia \\ ikaarista20@gmail.com¹,yudho@mail.unnes.ac.id²
}

Masuk: 29 Nopember 2018, Diterima: 30 Desember 2018, Terbit: 7 January 2019

\begin{abstract}
The purpose of this research is to analyze the influence of financing fund adequacy, risk, credit assessment of 5C, accountability, internal control systems, and accounting information on financing quality at BNI Syariah Semarang. The population of this study is all employees of BNI Syariah Semarang which consist of 120 employees. Sampling technique used in this study is random sampling method. It uses the slovin's formula and obtains 55 respondents. The technique of data analysis used in this study is Structural Equation Modelling-Partial Least Square (SEM$P L S)$ with analysis tool of SmartPLS 3.0. The results of this research showed that the adequacy of financing funds, credit assessment of 5C, accountability, and accounting information have a significant and positive impact on financing quality. While risk and internal control systems don't have significant impact on financing quality.
\end{abstract}

Keywords: assessment; control; financing; quality; risk

\begin{abstract}
Abstrak
Tujuan penelitian ini adalah untuk menganalisis pengaruh kecukupan dana pembiayaan, risiko, penilaian 5C Kredit, akuntabilitas, sistem pengendalian internal, dan informasi akuntansi terhadap kualitas pembiayaan pada BNI Syariah Semarang. Populasi penelitian ini adalah seluruh pegawai BNI Syariah Semarang yaitu sebanyak 120 pegawai. Metode pengambilan sampel yang digunakan adalah metode random sampling. Dengan menggunakan rumus slovin diperoleh sebanyak 55 responden. Teknik analisis menggunakan Structural Equation Modelling-Partial Least Square (SEM-PLS) dengan alat analisis SmartPLS 3.0. Hasil penelitian menyatakan bahwa kecukupan dana pembiayaan, penilaian $5 \mathrm{C}$ kredit, akuntabilitas, dan informasi akuntansi berpengaruh positif dan signifikan terhadap kualitas pembiayaan. Sedangkan risiko dan sistem pengendalian internal tidak berpengaruh signifikan terhadap kualitas pembiayaan.
\end{abstract}

Kata Kunci: kualitas; pembiayaan; penilaian; risiko; pengendalian 


\section{PENDAHULUAN}

Bank merupakan lembaga keuangan yang menjalankan fungsi sebagai penghimpun dan penyalur dana masyarakat. Dalam perkembangannya, bank dibedakan menjadi dua yaitu bank konvensional dan bank syariah. Purnamawati, Yuniarta, dan Sulindawati (2014) menjelaskan bahwa bank syariah merupakan bank yang menjalankan usahanya berdasarkan prinsip syariah. Widodo dan Asas (2017) berpendapat bahwa bank syariah dalam menjalankan aktivitasnya berorientasi terhadap keuntungan. Keuntungan yang diperoleh tidak berasal dari bunga seperti pada bank konvensional, melainkan dari proses bagi hasil.

Anisykurlillah, Fachrurrozie, dan Mukhibad (2016) serta Andraeny (2011) menjelaskan bahwa perkembangan bank syariah di Indonesia sangat pesat, dilihat dari peningkatan jumlah bank syariah beserta asetnya. Machmud dan Rukmana (2009) menjelaskan bahwa terdapat tiga fungsi utama bank, yaitu menerima simpanan uang, meminjamkan uang, dan memberikan jasa pengiriman uang. Haryati (2009) menjelaskan bahwa penyaluran pembiayaan merupakan fokus utama perbankan dalam menjalankan fungsi intermediasi. Pembiayaan dibutuhkan oleh masyarakat untuk mengembangkan bisnisnya. Hal ini sepadan dengan hasil penelitian Prihadini dan Asrori (2017) yang menjelaskan bahwa pembiayaan berpengaruh signifikan terhadap perkembangan bisnis.

Widyawati dan Wahyudi (2016) menjelaskan bahwa meskipun pembiayaan mampu mendukung perekonomian negara, pembiayaan juga memiliki potensi adanya permasalahan bagi perekonomian negara. Oleh karena itu, sesuai dengan pendapat Rusmanto (2008) bahwa bank syariah harus berpedoman pada prinsip kehati-hatian untuk menghindari terjadinya pembiayaan bermasalah. Berikut ini merupakan data mengenai total pembiayaan beserta pembiayaan bermasalah (NPF) bank syariah di Indonesia beserta BNI Syariah Indonesia:

Tabel 1. Data Pembiayaan dan NPF Bank Syariah berdasarkan Jenis Penggunaan

\begin{tabular}{lrrrrrr}
\hline & 2013 & 2014 & 2015 & 2016 & 2017 & Jan-18 \\
\hline Pembiayaan & 1.477 .831 & 1.668 .303 & 1.921 .724 & 2.220 .852 & 2.454 .950 & 2.589 .673 \\
NPF & 96.124 & 131.557 & 157.614 & 191.765 & 255.534 & 274.590 \\
Persentase & $6,50 \%$ & $7,89 \%$ & $8,20 \%$ & $8,63 \%$ & $10,41 \%$ & $10,60 \%$ \\
NPF & & & & & & \\
\hline
\end{tabular}

Sumber: Statistik Perbankan Syariah (2018)

Tabel 2. Ikhtisar Kinerja BNI Syariah Tahun 2013 - 2017 (dalam Miliar Rupiah)

\begin{tabular}{lrrrrr}
\hline & 2013 & 2014 & 2015 & 2016 & 2017 \\
\hline Total Pembiayaan & 11.242 & 15.044 & 17.765 & 20.494 & 23.597 \\
NPF & $1,86 \%$ & $1,86 \%$ & $2,53 \%$ & $2,94 \%$ & $2,89 \%$ \\
\hline Sur
\end{tabular}

Sumber: Annual Report BNI Syariah (2017)

Berdasarkan data tersebut, nilai pembiayaan selalu mengalami peningkatan. Namun peningkatan pembiayaan tersebut disertai pula dengan adanya peningkatan NPF, yang menunjukkan adanya kualitas pembiayaan yang kurang baik. Peningkatan 
NPF tersebut dapat dikarenakan oleh beberapa faktor, seperti debitur yang tidak bertanggungjawab, kurangnya pengendalian internal, dan sebagainya. Oleh karena itu, sebelum melakukan pembiayaan pihak bank harus menilai dan menganalisis faktorfaktor yang dapat mempengaruhi pembiayaan.

Variabel pada penelitian ini diambil berdasarkan hasil penelitian terdahulu yang tidak konsisten. Dyatama dan Yuliadi (2015) serta Widodo dan Asas (2017) menjelaskan bahwa kecukupan dana pembiayaan dan risiko berpengaruh terhadap pembiayaan. Sedangkan Furqaini dan Yaya (2016) menjelaskan bahwa kecukupan dana pembiayaan dan risiko tidak berpengaruh terhadap pembiayaan. Yusuf, Hubeis, dan Hardjomidjojo (2010) serta Amin, Abdul Rahman, dan Abdul Razak (2014) menjelaskan bahwa salah satu dari aspek penilaian 5C kredit, yaitu character berpengaruh terhadap pembiayaan. Oka, Purnamawati, dan Sinarwati (2015) menjelaskan bahwa salah satu dari aspek penilaian 5C kredit, yaitu condition berpengaruh terhadap pembiayaan. Sedangkan Afandi (2010) menjelaskan bahwa character dan condition tidak berpengaruh terhadap pembiayaan, berbeda dengan aspek capacity dan collateral yang dinyatakan berpengaruh terhadap pembiayaan.

Handayani dan Zenita (2017) serta Ekaulandari dan Dwirandra (2013) menjelaskan bahwa sistem pengendalian internal mampu mempengaruhi efektivitas pembiayaan. Hasil ini berbeda dengan hasil penelitian Muzamil (2015). Agusthia (2012) menjelaskan bahwa informasi akuntansi dapat mempengaruhi pembiayaan. Sedangkan Gulo (2005) menjelaskan bahwa informasi akuntansi tidak mempengaruhi pembiayaan.

Tujuan penelitian ini adalah untuk menganalisis pengaruh kecukupan dana pembiayaan, risiko, penilaian 5C kredit, akuntabilitas, sistem pengendalian internal, dan informasi akuntansi terhadap kualitas pembiayaan. Orisinalitas dalam penelitian ini terdapat pada objek, yaitu BNI Syariah Semarang. Pada penelitian terdahulu, mayoritas menggunakan koperasi sebagai objek penelitian.

Penelitian ini dilakukan pada pegawai BNI Syariah Semarang yang terdiri dari 1 Kantor Cabang, 2 Kantor Cabang Pembantu, dan 1 Kantor Kas. Pemilihan BNI Syariah sebagai objek penelitian dikarenakan berdasarkan annual report 2017 pembiayaan yang dilakukan oleh BNI Syariah selalu meningkat. Selain itu, dari tahun 2013 hingga 2017 nilai pembiayaan bermasalah BNI Syariah juga cenderung meningkat. Berdasarkan informasi yang diperoleh dari Sitanggang dalam kontan.co.id (2017) BNI Syariah mengalami peningkatan pembiayaan bermasalah pada kuartal II 2017 setelah sebelumnya mengalami peningkatan penyaluran pembiayaan hingga Juni 2017. Sedangkan peneliti memilih Kota Semarang dikarenakan kantor BNI Syariah yang paling banyak di Jawa Tengah berada di Kota Semarang.

Penelitian ini didukung oleh Sharia Enterprise Theory (SET) dan Resources Based Theory (RBT). Sharia Enterprise Theory (SET) merupakan suatu teori yang menempatkan Tuhan sebagai pusat dari segala hal. Triyuwono (2011) menjelaskan bahwa dalam Sharia Enterprise Theory harus mementingkan para stakeholders, yang meliputi Tuhan, manusia, dan alam atau lingkungan. Segala hal yang dilakukan harus berdasarkan prinsip syariah. Dalam hal kekayaan, Tuhan menghendaki agar harta yang dimiliki dapat disalurkan kepada pihak yang membutuhkan. Oleh karena itu bank syariah melakukan penyaluran pembiayaan kepada debitur. Suatu bank syariah yang memiliki simpanan dana yang cukup tinggi akan memilih untuk memaksimalkan penyaluran 
dana kepada pihak yang membutuhkan dalam bentuk pembiayaan atau kredit. Dengan adanya simpanan dana, kegiatan penyaluran pembiayaan akan terus berlangsung dengan baik. Selain itu, kegiatan penyaluran pembiayaan juga merupakan salah satu bentuk implementasi perintah Tuhan, dimana apabila ada seorang yang memiliki kelebihan dana, maka ia wajib untuk menyalurkan sebagian dana atau harta yang dimiliki kepada seseorang yang merupakan defisit dana.

Resources Based Theory (RBT) merupakan teori yang menunjukkan pentingnya sebuah kemampuan para pegawai dalam mewujudkan tujuan entitas. Salah satu tujuan entitas yang berhubungan dengan pembiayaan adalah menghasilkan kegiatan penyaluran pembiayaan yang berkualitas. Oleh karena itu, Resources Based Theory (RBT) dapat digunakan untuk menjelaskan hubungan antara risiko, penilaian 5C kredit, akuntabilitas, sistem pengendalian internal, dan informasi akuntansi terhadap kualitas pembiayaan. Dalam hal meningkatkan kualitas pembiayaan, setiap pegawai pada bank syariah diharuskan untuk memiliki kemampuan yang baik dalam melakukan penilaian risiko, dalam menerapkan setiap bentuk pengendalian internal yang ada, dalam melakukan penilaian terhadap debitur, serta mampu menganalisis setiap informasi yang berkaitan dengan debitur.

Dalam melakukan pembiayaan, pihak bank harus memiliki dana pembiayaan yang cukup. Apabila dana pembiayaan menunjukkan jumlah yang tinggi, maka pembiayaan dapat berjalan lancar dan berkualitas baik. Hubungan antara kecukupan dana pembiayaan dan kualitas pembiayaan didasarkan pada Sharia Enterprise Theory (SET) dimana dana yang dimiliki oleh bank syariah harus disalurkan kepada debitur. Dengan adanya simpanan dana yang cukup, kegiatan penyaluran pembiayaan akan terus berlangsung dengan baik. Selain itu, kegiatan penyaluran pembiayaan juga merupakan salah satu perintah Tuhan, dimana apabila ada seorang yang memiliki kelebihan dana, maka ia wajib untuk menyalurkan sebagian dana atau harta yang dimiliki kepada seseorang yang kekurangan dana.

Hal ini sepadan dengan hasil penelitian Dyatama dan Yuliadi (2015) serta Widodo dan Asas (2017) yang menjelaskan bahwa kecukupan dana pembiayaan memiliki hubungan positif terhadap pembiayaan. Berdasarkan uraian tersebut maka dapat diajukan hipotesis pertama yaitu:

\section{$H_{1}$ : Kecukupan dana pembiayaan berpengaruh positif terhadap kualitas pembiayaan}

Risiko merupakan potensi kejadian yang berdampak negatif pada pencapaian tujuan bank. Dalam pembiayaan, risiko pada periode sebelumnya dapat digunakan untuk menentukan alokasi pembiayaan periode selanjutnya. Semakin besar nilai risiko pembiayaan, maka pihak bank syariah akan memperkecil alokasi dana untuk pembiayaan. Hal ini dilakukan dalam rangka mengantisipasi kemungkinan terjadinya risiko yang tinggi pada periode selanjutnya. Karena adanya risiko yang tinggi menandakan bahwa pembiayaan yang dilakukan memiliki kualitas yang kurang baik. Hubungan antara risiko dan kualitas pembiayaan dapat diperkuat oleh resouces based theory. Hal ini dikarenakan para pegawai harus memiliki kemampuan dalam menilai risiko yang dimiliki pada periode sebelumnya untuk menentukan jumlah alokasi dana pembiayaan pada periode 
selanjutnya, sehingga dapat memperkecil atau menekan risiko pada periode selanjutnya. Hal ini sepadan dengan hasil penelitian Dyatama dan Yuliadi (2015) serta Ekaulandari dan Dwirandra (2013) yang menjelaskan bahwa risiko berpengaruh negatif signifikan terhadap pembiayaan. Berdasarkan uraian tersebut maka dapat diajukan hipotesis kedua yaitu:

\section{$\mathrm{H}_{2}$ : Risiko berpengaruh negatif terhadap kualitas pembiayaan}

Penilaian 5C kredit merupakan suatu penilaian yang dilakukan oleh pihak bank syariah untuk menilai kelayakan calon debitur dalam mendapatkan pembiayaan. Mengingat besarnya risiko yang dapat dialami dari kegiatan pembiayaan, maka pihak bank syariah harus selektif dan hati-hati dalam menganalisis dan menentukan calon debitur yang akan diberikan pembiayaan. Apabila calon debitur yang mengajukan permintaan pembiayaan memiliki karakter yang kuat, kemampuan mengembalikan pinjaman yang baik, harta yang layak untuk dijadikan sebagai jaminan, kemampuan modal yang kuat, serta kondisi perekonomian yang aman, maka pihak bank syariah akan menyetujui untuk memberikan pembiayaan kepada calon debitur tersebut. Hal ini dikarenakan pihak bank menganggap bahwa calon debitur tersebut mampu melakukan tanggung jawabnya dengan baik, sehingga pembiayaan yang dilakukan dapat memiliki kualitas yang baik. Hubungan antara penilaian 5C kredit dan kualitas pembiayaan dapat diperkuat dengan resources based theory yang menjelaskan bahwa pihak bank harus memiliki kemampuan dalam menilai dan menganalisis segala informasi yang dimiliki oleh calon debitur agar pembiayaan yang dilakukan tidak membawa risiko yang tinggi. Hal ini sepadan dengan penelitian Yusuf et al. (2010), Magbul dan Hassan (2017), dan Oka et al. (2015) yang menjelaskan bahwa penilaian 5C kredit memiliki pengaruh positif terhadap pembiayaan. Berdasarkan uraian tersebut maka dapat diajukan hipotesis ketiga yaitu:

\section{$\mathrm{H}_{3}$ : Penilaian $5 \mathrm{C}$ kredit berpengaruh positif terhadap kualitas pembiayaan}

Akuntabilitas merupakan suatu bentuk pertanggungjawaban seseorang terkait dengan suatu hal. Dalam kegiatan pembiayaan, pihak bank diharuskan untuk memilih debitur yang memiliki akuntabilitas tinggi untuk mencegah kemungkinan adanya risiko pembiayaan. Seorang debitur dengan akuntabilitas tinggi akan memiliki rasa tanggung jawab yang tinggi pula terhadap pembiayaan yang diterimanya, sehingga debitur tersebut akan senantiasa membayar angsuran hingga akhir dan tidak ada pembiayaan macet yang terjadi. Hal ini menunjukkan bahwa pembiayaan yang dilakukan memiliki kualitas yang baik. Oleh karena itu pihak bank harus menilai debitur dengan baik sebelum melakukan pembiayaan. Hubungan antara akuntabilitas dengan kualitas pembiayaan dapat dijelaskan oleh resources based theory, dimana pihak bank dalam melakukan pembiayaan harus memiliki kemampuan dalam menilai akuntabilitas debitur untuk mencegah adanya pembiayaan macet atau bermasalah. Berdasarkan uraian tersebut maka dapat diajukan hipotesis ke-empat yaitu: 


\section{$\mathrm{H}_{4}$ : Akuntabilitas berpengaruh positif terhadap kualitas pembiayaan}

Sistem pengendalian internal merupakan suatu sistem yang menjelaskan bahwa kebijakan dan prosedur manajemen dalam perbankan telah dilaksanakan dengan baik. Kusumantoro, Nurkhin, Mukhibad, dan Kiswanto (2016) menjelaskan bahwa sistem pengendalian internal memegang peran paling penting dalam suatu entitas. Dalam pembiayaan, pengendalian internal dapat dilakukan dalam bentuk pembinaan dan pengawasan terhadap pembiayaan bermasalah sehingga dapat meminimalisir terjadinya risiko pembiayaan. Apabila sistem pengendalian internal telah diterapkan dengan baik oleh pihak bank syariah, maka pembiayaan yang dilakukan dapat berkualitas baik. Hubungan antara sistem pengendalian internal dengan kualitas pembiayaan dapat diperkuat dengan resources based theory, dimana pihak bank diharuskan untuk mampu menerapkan segala bentuk pengendalian internal terkait dengan pembiayaan dengan baik untuk dapat memperoleh kualitas yang baik dari kegiatan pembiayaan. Hal ini sepadan dengan hasil penelitian Ekaulandari dan Dwirandra (2013) serta Handayani dan Zenita (2017) yang menjelaskan bahwa sistem pengendalian internal berpengaruh positif signifikan terhadap pembiayaan. Berdasarkan uraian tersebut maka dapat diajukan hipotesis kelima yaitu:

\section{$\mathrm{H}_{5}$ : Sistem pengendalian internal berpengaruh positif terhadap kualitas pembiayaan}

Informasi akuntansi merupakan suatu informasi mengenai kondisi keuangan debitur yang akan digunakan oleh pihak bank untuk menetapkan keputusan mengenai pemberian pembiayaan. Informasi akuntansi dinilai memiliki pengaruh terhadap kualitas pembiayaan. Apabila informasi akuntansi debitur menunjukkan hasil yang baik maka pihak bank akan menyalurkan pembiayaan terhadap debitur tersebut. Hubungan informasi akuntansi dengan kualitas pembiayaan dapat diperkuat dengan resources based theory, dimana pihak bank diharuskan untuk memiliki kemampuan dalam menilai dan menganalisis informasi akuntansi, sehingga tidak salah dalam memilih debitur yang akan diberikan pembiayaan. Apabila pihak bank dapat memilih debitur yang layak, maka pembiayaan yang dilakukan akan berkualitas baik karena debitur tersebut tidak akan lalai dalam membayar angsuran. Hal ini sepadan dengan hasil penelitian Salim dan Poputra (2015) serta Agusthia (2012) yang menjelaskan bahwa informasi akuntansi berpengaruh terhadap pembiayaan. Berdasarkan uraian tersebut maka dapat diajukan hipotesis ke-enam yaitu:

\section{$\mathrm{H}_{6}$ : Informasi akuntansi berpengaruh positif terhadap kualitas pembiayaan}

Berdasarkan uraian kerangka pemikiran teoritis dan pengembangan hipotesis di atas, maka penelitian ini menggunakan model kerangka pemikiran pada Gambar 1. 


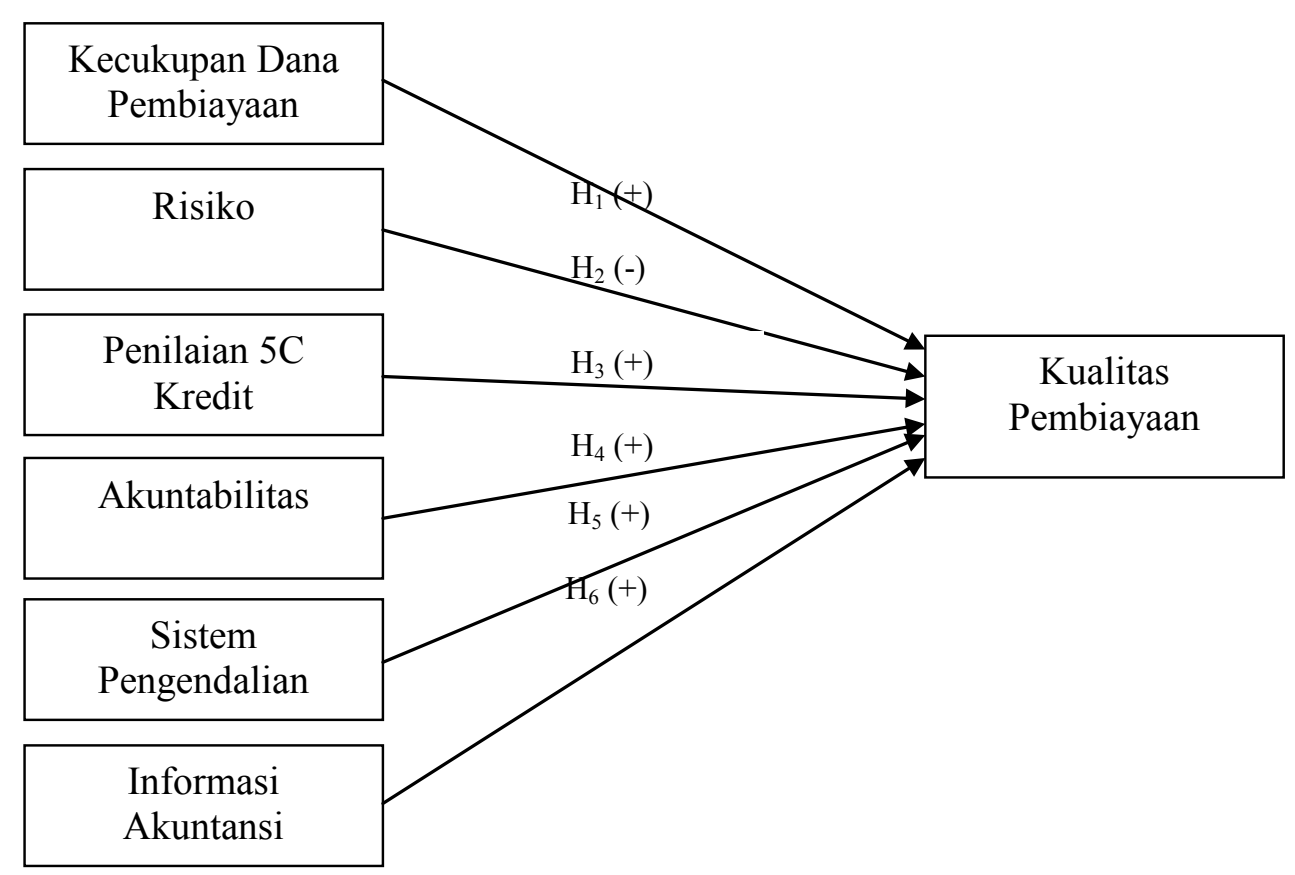

Gambar 1. Kerangka Berpikir

\section{METODE PENELITIAN}

Jenis penelitian ini merupakan penelitian kuantitatif. Data yang digunakan merupakan data primer yang diperoleh dari kuesioner yang disebarkan kepada pegawai BNI Syariah Semarang. Populasi penelitian yaitu seluruh pegawai BNI Syariah Semarang yang berjumlah 120 pegawai. Sedangkan sampel penelitian adalah 55 pegawai BNI Syariah Semarang yang diperoleh melalui rumus slovin. Teknik sampling yang digunakan adalah random sampling. Analisis data menggunakan Structural Equation Modelling-Partial Least Square (SEM-PLS) dengan alat analisis SmartPLS 3.0. Hal ini dikarenakan data yang dibutuhkan dalam SEM-PLS tidak terlalu besar. Sedangkan data pada penelitian ini kurang dari 100 responden. Selain itu, data yang digunakan tidak harus berdistribusi normal. Tabel 3 berikut ini menjelaskan terkait definisi operasional variabel yang ada dalam penelitian ini:

Tabel 3. Definisi Operasional Variabel Penelitian

\begin{tabular}{lllll}
\hline No & \multicolumn{1}{c}{ Variabel } & \multicolumn{1}{c}{ Definisi } & \multicolumn{1}{c}{ Indikator } & Pengukuran \\
\hline 1. & Kualitas & Suatu kondisi yang & Keamanan & Skala Likert \\
& Pembiayaan (Y) & $\begin{array}{l}\text { menggambarkan bentuk } \\
\text { keberhasilan dari }\end{array}$ & Terarahnya tujuan & empat poin \\
& & pembiayaan & \\
& & & Menguntungkan \\
& & & \\
& & & & \\
\hline
\end{tabular}


Lanjutan Tabel 3. Definisi Operasional Variabel Penelitian

\begin{tabular}{|c|c|c|c|c|}
\hline No & Variabel & Definisi & Indikator & Pengukuran \\
\hline 2. & $\begin{array}{l}\text { Kecukupan Dana } \\
\text { Pembiayaan (X1) }\end{array}$ & $\begin{array}{l}\text { Suatu keadaan dima- } \\
\text { na pihak bank memi- } \\
\text { liki jumlah dana } \\
\text { yang cukup untuk } \\
\text { melaksanakan kegia- } \\
\text { tan pembiayaan. }\end{array}$ & 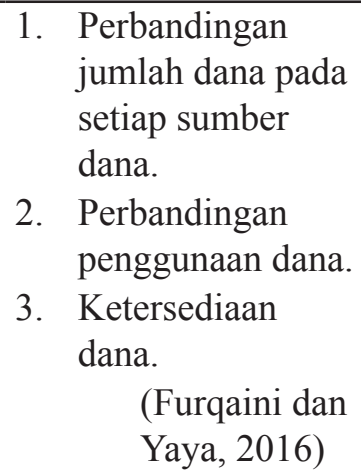 & $\begin{array}{l}\text { Skala Likert } \\
\text { empat poin }\end{array}$ \\
\hline 3. & Risiko (X2) & $\begin{array}{l}\text { Suatu kejadian yang } \\
\text { berasal dari adanya } \\
\text { kegiatan operasional } \\
\text { bank yang dilaku- } \\
\text { kan. }\end{array}$ & $\begin{array}{l}\text { 1. Unsur kompetensi } \\
\text { 2. Unsur jaminan } \\
\text { 3. Unsur persaingan } \\
\text { 4. Unsur } \\
\text { kesengajaan } \\
\text { (Rahman, 2017) }\end{array}$ & $\begin{array}{l}\text { Skala Likert } \\
\text { empat poin }\end{array}$ \\
\hline 4. & $\begin{array}{l}\text { Penilaian 5C } \\
\text { Kredit (X3) }\end{array}$ & $\begin{array}{l}\text { Suatu penilaian yang } \\
\text { dilakukan oleh pihak } \\
\text { bank untuk menga- } \\
\text { nalisis hal - hal yang } \\
\text { berkaitan dengan } \\
\text { calon debitur, seperti } \\
\text { character, capacity, } \\
\text { capital, collateral, } \\
\text { dan condition. }\end{array}$ & $\begin{array}{l}\text { 1. Character : } \\
\text { a. Itikad dan tang- } \\
\text { gung jawab } \\
\text { b. Watak } \\
\text { c. Komitmen } \\
\text { pembayaran } \\
\text { 2. Capacity: } \\
\text { a. Sumber peng- } \\
\text { hasilan } \\
\text { b. Kemampuan } \\
\text { membayar } \\
\text { c. Kemampuan } \\
\text { menyelesaikan } \\
\text { pinjaman tepat } \\
\text { waktu } \\
\text { Capital : } \\
\text { a. Mempunyai } \\
\text { sumber peng- } \\
\text { hasilan tetap } \\
\text { b. Memiliki } \\
\text { bidang usaha } \\
\text { lain sebagai } \\
\text { sumber peng- } \\
\text { hasilan }\end{array}$ & $\begin{array}{l}\text { Skala Likert } \\
\text { empat poin }\end{array}$ \\
\hline
\end{tabular}


Lanjutan Tabel 3. Definisi Operasional Variabel Penelitian

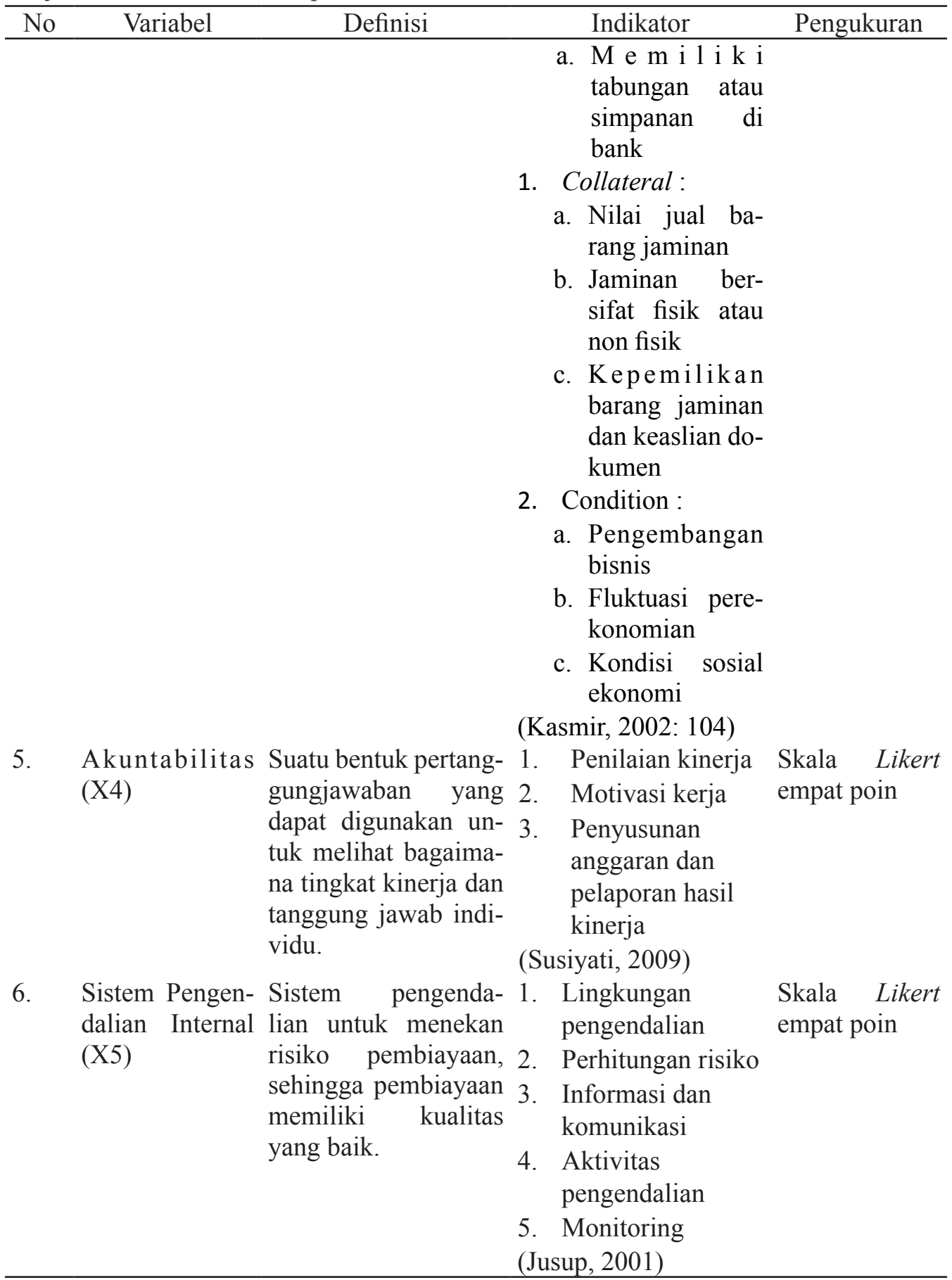


Lanjutan Tabel 3. Definisi Operasional Variabel Penelitian

\begin{tabular}{lllll}
\hline No & Variabel & Definisi & Indikator & Pengukuran \\
\hline 7. & Informasi & Informasi kuantitatif & Hutang piutang & Skala Likert \\
& Akuntansi & mengenai entitas & perusahaan & empat poin \\
& (X6) & ekonmi yang & Kinerja perusahaan & \\
& & bermanfaat untuk & Laporan keuangan & \\
& & pengambilan & lengkap & \\
& keputusan dalam & Kekayaan perusahaan & \\
& memilih debitur yang & Proyeksi biaya dan & \\
& layak untuk diberikan & sumber dana & \\
& pembiayaan. & Nilai perusahaan & \\
& & (Simanjuntak, 1999) & \\
& & & \\
\hline
\end{tabular}

Sumber: Peneliti (2018)

\section{HASIL DAN PEMBAHASAN}

Penelitian ini menggunakan 55 responden dari pegawai BNI Syariah Semarang. Seluruh data dari 55 responden penelitian dapat diolah. Dalam analisis SEM-PLS dilakukan tiga pengujian, yaitu uji outer model atau model pengukuran, uji inner model atau model struktural, dan uji hipotesis. Pertama, uji outer model digunakan untuk menguji validitas dan reliabilitas. Puspitasari dan Jayanto (2017) dalam penelitiannya menjelaskan bahwa outer model digunakan untuk menunjukkan bagaimana variabel manifes mewakili variabel laten. Kriteria penilaian outer model yang digunakan adalah validitas convergent yang dilihat dari loading factor dan Average Variance Extracted (AVE) serta reliabilitas yang dilihat dari nilai cronbach's alpha dan composite reliability. Kedua, uji inner model digunakan untuk mengetahui besarnya pengaruh antar variabel laten. Ketiga, uji hipotesis digunakan untuk mengetahui ada atau tidaknya pengaruh antar variabel laten.

Penilaian outer model menggunakan nilai loading factor dan Average Variance Extracted (AVE). Berdasarkan hasil output penelitian, nilai outer loadings menunjukkan bahwa seluruh konstruk memiliki nilai loading factors di atas 0,7 sehingga dianggap telah memenuhi syarat validitas. Dilihat dari nilai AVE, seluruh variabel laten memiliki nilai AVE di atas 0,5 sehingga telah memenuhi syarat validitas, serta menunjukkan bahwa setiap indikator penelitian dapat mengukur variabel penelitian.

Uji reliabilitas diukur dengan dua kriteria, yaitu cronbach's alpha dan composite reliability. Berdasarkan hasil output penelitian menunjukkan bahwa seluruh variabel memiliki nilai cronbach's alpha dan composite reliability di atas 0,7 sehingga dianggap telah memenuhi syarat reliabilitas, serta menunjukkan bahwa instrumen penelitian yang digunakan memiliki konsistensi dan stabilitas yang tinggi.

Uji inner model dapat dilihat dari nilai $R$-Square. Berdasarkan hasil output penelitian nilai $R$-Square sebesar 0,924 , sehingga menjelaskan bahwa variabel laten dependen dapat dijelaskan oleh variabel laten independen sebesar $92,4 \%$. Sedangkan sisanya sebesar 7,6\% dijelaskan oleh faktor lain yang tidak dijelaskan dalam model.

Berdasarkan hasil output SmartPLS 3.0, berikut ini merupakan hasil pengujian hipotesis penelitian pada Tabel 3: 
Tabel 4. Hasil Pengujian Hipotesis Penelitian

\begin{tabular}{llccc}
\hline Hipotesis & \multicolumn{1}{c}{ Pernyataan } & $\begin{array}{c}\text { Original } \\
\text { Sample (O) }\end{array}$ & P Values & Hasil \\
\hline $\mathrm{H}_{1}$ & $\begin{array}{l}\text { Kecukupan dana pembiayaan } \\
\text { berpengaruh positif terhadap kualitas } \\
\text { pembiayaan }\end{array}$ & 0,240 & 0,008 Diterima \\
$\mathrm{H}_{2}$ & $\begin{array}{l}\text { Risiko berpengaruh negatif terhadap } \\
\text { kualitas pembiayaan }\end{array}$ & 0,229 & 0,020 Ditolak \\
$\mathrm{H}_{3}$ & $\begin{array}{l}\text { Penilaian 5C kredit berpengaruh positif } \\
\text { terhadap kualitas pembiayaan }\end{array}$ & 0,202 & 0,004 Diterima \\
$\mathrm{H}_{4}$ & $\begin{array}{l}\text { Akuntabilitas berpengaruh positif } \\
\text { terhadap penyaluran pembiayaan }\end{array}$ & 0,270 & 0,009 Diterima \\
$\mathrm{H}_{5}$ & $\begin{array}{l}\text { Sistem pengendalian internal } \\
\text { berpengaruh positif terhadap kualitas } \\
\text { pembiayaan }\end{array}$ & 0,081 & 0,463 Ditolak \\
$\mathrm{H}_{6}$ & $\begin{array}{l}\text { Informasi akuntansi berpengaruh positif } \\
\text { terhadap kualitas pembiayaan }\end{array}$ & 0,061 & 0,499 Diterima \\
\hline
\end{tabular}

Sumber: Output SmartPLS 3.0. (2018)

Uji hipotesis dilakukan dengan melihat nilai path coefficient yang menunjukkan koefisien parameter dan nilai t-statistic atau $p$ values. Penelitian ini menggunakan tingkat keyakinan 95\%. Dalam penilaian hipotesis yang menggunakan $\mathrm{p}$ values, hipotesis diterima apabila nilai $\mathrm{p}$ values $<0,05$.

\section{Pengaruh Kecukupan Dana Pembiayaan terhadap Kualitas Pembiayaan}

Berdasarkan uji hipotesis diperoleh nilai $p$ values sebesar 0,008 , dibawah 0,05 . Sedangkan nilai dari original sampel adalah positif sebesar 0,240 . Hal ini menunjukkan adanya pengaruh positif signifikan antara kecukupan dana pembiayaan terhadap kualitas pembiayaan. Dengan demikian, $\mathrm{H}_{1}$ yang menyatakan kecukupan dana pembiayaan berpengaruh positif terhadap kualitas pembiayaan diterima.

Hal ini sesuai dengan Sharia Enterprise Theory (SET) yang menjelaskan bahwa dalam melakukan suatu hal harus menempatkan Allah sebagai pusat segala hal. Proses pembiayaan pada bank syariah menganut pada prinsip islam yang menjelaskan bahwa dana atau harta yang dimiliki oleh setiap individu tidak boleh ditimbun, melainkan harus disalurkan kepada yang membutuhkan. Dalam bank syariah, proses penyaluran dana atau pembiayaan dapat diberikan kepada debitur yang merupakan defisit dana atau yang sedang membutuhkan dana. Dengan adanya simpanan dana yang cukup tinggi, maka hal tersebut dapat menghasilkan kegiatan penyaluran pembiayaan yang lebih baik. Hal ini dikarenakan penyaluran pembiayaan tidak mengalami hambatan terkait dengan ketersediaan dana. Hasil penelitian ini sepadan dengan hasil penelitian Dyatama dan Yuliadi (2015) serta Widodo dan Asas (2017) yang menjelaskan bahwa dana pembiayaan memiliki hubungan yang positif terhadap pembiayaan.

\section{Pengaruh Risiko terhadap Kualitas Pembiayaan}

Berdasarkan uji hipotesis diperoleh nilai $p$ values sebesar 0,463 sehingga hipotesis ditolak. Selain itu, nilai original sampel adalah positif 0,081 . Hal ini menjelaskan bahwa 
tidak ada pengaruh yang signifikan antara risiko dengan kualitas pembiayaan. Pihak BNI Syariah Semarang tidak menggunakan nilai risiko pembiayaan periode sebelumnya sebagai patokan dalam melakukan pembiayaan. Meskipun nilai risiko pada periode sebelumnya mengalami peningkatan, pihak BNI Syariah Semarang tidak menggunakan nilai risiko tersebut sebagai patokan dalam menentukan alokasi pembiayaan yang akan disalurkan untuk periode selanjutnya. Bahkan pihak BNI Syariah Semarang tetap melakukan peningkatan terhadap jumlah pembiayaan yang disalurkan.

Pihak bank syariah memiliki keberanian yang tinggi untuk menghadapi adanya risiko dari kegiatan pembiayaan. Apabila pihak BNI Syariah Semarang berani untuk mengalokasikan jumlah penyaluran pembiayaan yang tinggi, maka pihak BNI tersebut juga harus berani dalam menanggung kemungkinan adanya risiko pembiayaan yang tinggi pula. Dalam hal ini, pihak BNI Syariah Semarang lebih mementingkan tingginya tingkat penyaluran pembiayaan tanpa memperhatikan aspek kualitas yang ditentukan dari tingginya nilai risiko pembiayaan. Sehingga pihak BNI Syariah Semarang tidak menggunakan nilai risiko pembiayaan periode sebelumnya sebagai patokan untuk mengurangi alokasi penyaluran pembiayaan. Dengan demikian, $\mathrm{H}_{2}$ yang menyatakan bahwa risiko berpengaruh negatif terhadap kualitas pembiayaan adalah ditolak.

Resources based theory menjelaskan bahwa kemampuan dari para pegawai dapat mempengaruhi hasil kinerja entitas yang bersangkutan. Para pegawai diharuskan memiliki kemampuan menilai risiko untuk dijadikan sebagai patokan dalam melakukan pembiayaan sehingga dapat berkualitas baik. Dalam BNI Syariah Semarang, kemampuan menilai risiko tidak dapat mempengaruhi kegiatan pembiayaan yang dilakukan. Hasil penelitian ini sebanding dengan hasil penelitian Furqaini dan Yaya (2016) yang menjelaskan bahwa risiko tidak memiliki pengaruh terhadap pembiayaan yang dilakukan.

\section{Pengaruh Penilaian 5C Kredit terhadap Kualitas Pembiayaan}

Berdasarkan uji hipotesis diperoleh nilai $\mathrm{p}$ values sebesar 0,009 , sedangkan nilai original sampel adalah positif sebesar 0,270 , sehingga hipotesis diterima. Hal ini menunjukkan bahwa terdapat pengaruh positif signifikan antara penilaian $5 \mathrm{C}$ kredit dengan kualitas pembiayaan. Dengan demikian, $\mathrm{H}_{3}$ yang menyatakan bahwa penilaian $5 \mathrm{C}$ kredit berpengaruh positif terhadap kualitas pembiayaan adalah diterima.

Hal ini sesuai dengan resources based theory yang menjelaskan bahwa pihak bank harus mampu melakukan penilaian terhadap debitur sebelum melakukan pembiayaan. Salah satu penilaian yang dilakukan yaitu terkait dengan 5C, yaitu character, capacity, capital, collateral, dan condition. Apabila debitur yang diberi pembiayaan memiliki penilaian 5C kredit yang baik, maka debitur tersebut akan senantiasa melakukan pembayaran angsuran, sehingga pembiayaan yang dilakukan dapat berkualitas baik. Oleh karena itu, penilaian harus dilakukan dengan teliti dan hati-hati untuk dapat memperoleh debitur yang memiliki penilaian 5C yang baik. Hasil ini sebanding dengan hasil penelitian Magbul dan Hassan (2017). Sedangkan Oka et al. (2015) dalam penelitiannya menjelaskan bahwa condition, capital, dan collateral sebagai aspek penilaian 5C kredit juga memiliki pengaruh positif terhadap pembiayaan.

\section{Pengaruh Akuntabilitas terhadap Kualitas Pembiayaan}

Berdasarkan uji hipotesis diperoleh nilai $\mathrm{p}$ values sebesar 0,004 . Selain itu, nilai original sampel adalah positif sebesar 0,202 , sehingga hipotesis diterima. Hal 
ini menunjukkan bahwa terdapat pengaruh positif signifikan antara akuntabilitas dan kualitas pembiayaan. Sehingga $\mathrm{H}_{4}$ yang menyatakan akuntabilitas berpengaruh positif terhadap kualitas pembiayaan adalah diterima.

Dalam melakukan pembiayaan, pihak bank wajib melakukan penilaian terhadap akuntabilitas debitur. Akuntabilitas merupakan suatu bentuk tanggung jawab seseorang terhadap suatu hal. Semakin tinggi tingkat akuntabilitas yang dimiliki oleh debitur, maka debitur tersebut pasti memiliki tanggung jawab yang tinggi terhadap pembiayaan yang diterimanya. Dengan adanya tanggung jawab yang dimiliki oleh debitur, maka debitur tersebut akan senantiasa membayar angsuran hingga akhir. Sehingga kemungkinan adanya risiko pembiayaan akan sangat kecil dan pembiayaan akan berkualitas baik.

Hal ini sepadan dengan resources based theory yang menjelaskan bahwa hasil yang dimiliki entitas akan bergantung pada kemampuan yang dimiliki oleh pegawainya. Dalam hal pembiayaan, pihak bank harus memiliki kemampuan menilai debitur dengan baik agar pihak bank tidak salah memilih debitur yang akan diberikan pembiayaan, sehingga pembiayaan yang dilakukan akan berkualitas baik.

\section{Pengaruh Sistem Pengendalian Internal terhadap Kualitas Pembiayaan}

Berdasarkan uji hipotesis diperoleh nilai $\mathrm{p}$ values sebesar 0,499. Selain itu, nilai dari original sampel adalah positif 0,061 , sehingga hipotesis ditolak. Hal ini menunjukkan tidak adanya pengaruh antara sistem pengendalian internal terhadap kualitas pembiayaan. Meskipun penerapan pengendalian internal terkait pembiayaan yang ada pada BNI Syariah Semarang kurang optimal, pihak BNI Syariah Semarang tetap melakukan pembiayaan dengan alokasi yang semakin meningkat. Hal ini dikarenakan pihak BNI Syariah lebih mementingkan tingginya penyaluran pembiayaan tanpa dibarengi dengan adanya strategi untuk memperkecil tingkat risiko yang ada.

Resources based theory menjelaskan bahwa keberhasilan usaha suatu entitas didasarkan pada bagaimana kemampuan yang dimiliki oleh setiap pegawainya. Dalam penerapan sistem pengendalian internal, pihak bank diharuskan untuk mampu menerapkan setiap bentuk pengendalian internal terkait pembiayaan dengan optimal untuk menghasilkan pembiayaan yang berkualitas. Dalam BNI Syariah Semarang, sistem pengendalian internal tidak mampu mempengaruhi kualitas pembiayaan yang dilakukan. Sehingga meskipun pengendalian internal yang dilakukan telah optimal, hal ini tidak menjamin adanya pembiayaan yang berkualitas. Pihak BNI Syariah Semarang belum menerapkan pengendalian internal dengan optimal. Hal ini dibuktikan dengan hasil jawaban responden yang menjelaskan bahwa pihak manajemen belum mampu menangani adanya risiko pembiayaan, struktur organisasi yang masih kurang jelas, serta kurangnya pemantauan dan pemeriksaan mendadak. Meskipun penerapan pengendalian internal terkait pembiayaan yang ada pada BNI Syariah Semarang kurang optimal, namun pihak BNI Syariah Semarang tetap melakukan pembiayaan dengan jumlah yang meningkat pada setiap tahunnya. Meskipun peningkatan pembiayaan ini juga diikuti dengan peningkatan pembiayaan bermasalah. Dengan adanya hal tersebut, pihak BNI Syariah Semarang dinilai memiliki keberanian yang tinggi dalam mengambil risiko pembiayaan yang ada. Hasil penelitian ini sepadan dengan hasil penelitian Muzamil (2015), yang menjelaskan bahwa penerapan sistem pengendalian internal penyaluran kredit pada BRI Kota Samarinda (BRI Unit Karang Paci Samarinda) masih terdapat beberapa kekurangan sehingga hasil penyaluran kredit yang dilakukan oleh BRI Kota 
Samarinda kurang baik.

\section{Pengaruh Informasi Akuntansi terhadap Kualitas Pembiayaan}

Berdasarkan uji hipotesis diperoleh nilai p values sebesar 0,020, sedangkan nilai original sampel adalah positif 0,229 , sehingga hipotesis diterima. Hal ini menunjukkan adanya pengaruh positif signifikan antara informasi akuntansi terhadap kualitas pembiayaan. Sehingga $\mathrm{H}_{6}$ yang menyatakan bahwa informasi akuntansi berpengaruh positif terhadap kualitas pembiayaan adalah diterima.

Berdasarkan resources based theory, para pegawai diharuskan memiliki kemampuan yang baik dalam melakukan segala kegiatan sehingga mampu mendapatkan hasil yang baik. Dalam hal pembiayaan, pihak bank diharuskan untuk memiliki kemampuan yang baik dalam menilai dan menganalisis informasi akuntansi yang dimiliki oleh debitur. Karena informasi akuntansi merupakan hal yang dapat menjelaskan bagaimana keberhasilan usaha debitur. Apabila debitur yang diberikan pembiayaan memiliki informasi akuntansi yang lengkap, akurat, serta menunjukkan kondisi keuangan yang baik, maka pihak bank akan melakukan penyaluran pembiayaan terhadap debitur tersebut. Hal ini dilakukan karena pihak bank yakin bahwa debitur tersebut memiliki kemampuan untuk membayar dan melunasi pembiayaan yang telah diterima, sehingga pembiayaan yang dilakukan dapat berkualitas baik. Oleh karena itu, pihak bank harus teliti dan hati-hati dalam menilai dan menganalisis informasi akuntansi, sehingga dapat memilih debitur yang benar-benar layak untuk diberikan pembiayaan. Hasil penelitian ini sepadan dengan hasil penelitian Salim dan Poputra (2015) serta Agusthia (2012) yang menjelaskan bahwa informasi akuntansi memiliki pengaruh terhadap penyaluran pembiayaan.

\section{KESIMPULAN}

Kecukupan dana pembiayaan berpengaruh positif signifikan terhadap kualitas pembiayaan. Risiko tidak berpengaruh signifikan terhadap kualitas pembiayaan. Penilaian 5C kredit berpengaruh positif signifikan terhadap kualitas pembiayaan. Akuntabilitas berpengaruh positif signifikan terhadap kualitas pembiayaan. Sistem pengendalian internal tidak berpengaruh signifikan terhadap kualitas pembiayaan. Informasi akuntansi berpengaruh positif signifikan terhadap kualitas pembiayaan.

Saran yang dapat diberikan untuk penelitian selanjutnya adalah menggunakan responden pegawai bagian pembiayaan agar data yang diperoleh menjadi lebih valid karena terfokus pada bagian yang berkaitan dengan fokus penelitian. Pihak BNI Syariah Semarang sebaiknya lebih sering melakukan monitoring dan pemberian peringatan serta penagihan untuk mengurangi pembiayaan bermasalah. Selain itu, pihak BNI Syariah sebaiknya lebih sering memberikan motivasi serta pelatihan kepada pegawai BNI Syariah Semarang agar dapat memperoleh hasil kinerja yang optimal.

\section{DAFTAR PUSTAKA}

Afandi, P. (2010). Analisis Implementasi 5C Bank BPR dalam Menentukan Kelayakan Pemberian Kredit pada Nasabah (Studi Kasus Pada PD BPR Bank Salatiga dan PT BPR Kridaharta Salatiga). Jurnal Ilmiah Among Makarti, 3(5), 55-69.

Agusthia, H. (2012). Analisis Pengaruh Informasi Akuntansi dan Informasi Non Akuntansi 
terhadap Keputusan Kredit. Accounting Analysis Journal, 1(2), 1-6.

Amin, H., Rahman, A. R. A, \& Razak, D. A. (2014). Consumer Acceptance of Islamic Home Financing. International Journal of Housing Markets and Analysis, 7(3), 307-332.

Andraeny, D. (2011). Analisis Pengaruh Dana Pihak Ketiga, Tingkat Bagi Hasil, dan Non Performing Financing terhadap Volume Pembiayaan Berbasis Bagi Hasil pada Perbankan Syariah di Indonesia. Simposium Nasional Akuntansi XIV, 47, 1-28.

Anisykurlillah, I., Fachrurrozie, \& Mukhibad, H. (2016). A Financial Report Model For Traditional Market Traders To Increase Mudharabah Financing In Baitul Maal Wattamwil (BMT). Review of Integrative Business dan Economics Research, 5(1), 219-228.

Dyatama, A. N., \& Yuliadi, I. (2015). Determinan Jumlah Pembiayaan Bank Syariah di Indonesia. Jurnal Ekonomi dan Studi Pembangunan, 16(1), 73-83.

Ekaulandari, N. W. V., \& Dwirandra, A. A. N. B (2013). Pengaruh Penaksiran Resiko, Iinformasi dan Komunikasi, Aktivitas Pengendalian, Pemantauan, Lingkungan Pengendalian pada Efektivitas Sistem Pemberian Kredit. E-Jurnal Akuntansi, 4(3), 585-604.

Furqaini, N., \& Yaya, R. (2016). Faktor-faktor yang Mempengaruhi Volume dan Porsi Pembiayaan Berbasis Bagi Hasil Pada Perbankan Syariah di Indonesia. JRAK (Jurnal Riset Akuntansi Dan Komputerisasi Akuntansi), 7(1), 22-38.

Gulo, S. A. (2005). Pengaruh Informasi Akuntansi dan Bukan Akuntansi Terhadap Persetujuan Kredit Yasa Griya Pada PT. Bank Tabungan Negara (Persero) Kantor Cabang Medan. Tesis. Pascasarjana Universitas Sumatera Utara.

Handayani, F., \& Zenita, Z. (2017). Pengaruh Sistem Pengendalian Intern terhadap Penyaluran Kredit pada Bank Kaltim Cabang Syariah Balikpapan. Jurnal Ilmiah Akuntansi Dan Keuangan, 6(2), 65-96.

Haryati, S. (2009). Pertumbuhan Kredit Perbankan di Indonesia: Intermediasi dan Pengaruh Variabel Makro Ekonomi. Jurnal Keuangan dan Perbankan, 13(2), 299-310.

Jusup. A. H. (2001). Auditing. Yogyakarta: Penerbit STIE YKPN.

Kasmir. (2002). Bank dan Lembaga Keuangan Lainnya. Jakarta: PT Raja Grafindo Persada.

Kurniasih, N. A. (2014). Pengaruh Sistem Pengendalian Internal Pemerintahan (SPIP) dan Akuntabilitas Terhadap Kualitas Laporan Keuangan Pemerintah Daerah (Studi Kasus pada Dinas Pengelolaan Keuangan dan Aset Daerah Kota Bandung). Skripsi: Universitas Widyatama.

Kusumantoro, Nurkhin, A., Mukhibad, H., \& Kiswanto. (2016). Determinants of Fraud Based on Islamic Paradigm: Case Study in Islamic Financial Services Cooperatives. International Journal of the Computer, the Internet and Management, 24(3), 68-71.

Machmud, A., \& Rukmana. (2009). Bank Syariah: Teori, Kebijakan, dan Studi Empiris di Indonesia. Jakarta: Erlangga.

Magbul, A., \& Hassan, R. (2017). Microcredit supply under Islamic Banking in Khartoum State, Sudan. Southern African Business Review, 21(1), 407-428.

Muzamil, M. (2015). Analisis Penerapan Sistem Pengendalian Internal Penyaluran Kredit pada BRI Kota Samarinda (Studi Kasus di BRI KCP Unit Karang Paci Samarinda). E-Journal Ilmu Administrasi Bisnis, 3(3), 661-674.

Oka, K. W. L., Purnamawati, I. G. A., \& Sinarwati, N. K. (2015). Pengaruh Dana Pihak Ketiga, Penilaian 5C Kredit, dan Kualitas Kredit Terhadap Keputusan Pemberian Kredit di PT. Bank Pembangunan Daerah Bali Cabang Singaraja. E-Journal S1 Ak Universitas Pendidikan Ganesha Jurusan Akuntansi Program S1, 3(1).

Prihadini, T., \& Asrori, A. (2017). The influence of Islamic Microfinance Against Welfare Customer BMT. Accounting Analysis Journal, 6(1), 107-114.

Purnamawati, I. G. A., Yuniarta, G. A., \& Sulindawati, N. L. G. E. (2014). Akuntansi Perbankan Teori dan Soal Latihan. Yogyakarta: Graha Ilmu.

Puspitasari, C., \& Jayanto, P. Y. (2017). The Influence of Selling Price Pricing, Margin Level, 
Product Quality, Shariah Marketing, Collateral, Product Knowledge and Risk on Member's Interest in Using Murabahah Financing. Accounting Analysis Journal, 5(3), 229-237.

Rahman, F. A. (2017). Pengaruh Kelayakan Pembiayaan Murabahah Terhadap non Performing Loan (NPL) (Studi Pada Bank Pembiayaan Rakyat Syariah (BPRS) Harta Insan Karimah Ciledug). Skripsi. Fakultas Ekonomi dan Bisnis UIN Syarif Hidayatullah Jakarta.

Rusmanto, R. (2008). Pengaruh Karakteristik Kualitatif Laporan Keuangan terhadap Penggunaannya dalam Pengambilan Keputusan Kredit Bank Umum di Banjarmasin. Ekuitas (Jurnal Ekonomi Dan Keuangan), 12(1), 53-73.

Salim, F. A., \& Poputra, A. T. (2015). Analisis Penerapan Sitem Informasi Akuntansi dalam Mendukung Pengendalian Internal Pemberian Kredit pada PT. Bank Bukopin Manado. Jurnal EMBA: Jurnal Riset Ekonomi, Manajemen, Bisnis dan Akuntansi, 3(1), 1034-1043.

Simanjuntak, A. T. (1999). Analisis Kebutuhan Informasi Akuntansi dan Informasi bukan Akuntansi dalam Pengambilan Keputusan Kredit Studi Kasus Perbankan di Kota Madya Semarang. Tesis. Program Pascasarjana Universitas Diponegoro.

Sitanggang, L. M. S. (2017). Pembiayaan Bermasalah BNI Syariah Mendaki. Retrieved March 20, 2018, from http://keuangan.kontan.co.id/news/pembiayaan-bermasalah-bni-syariahmendaki

Susiyati, T. (2009). Pengaruh Akuntansi Pertanggungjawaban pada Penyaluran Dana Zakat Produktif. Trikonomika Journal, 8(1), 32-38.

Triyuwono, I. (2011). Mengangkat “Sing Liyan” untuk Formulasi Nilai Tambah Syari'ah. Jurnal Akuntansi Multiparadigma, 2(2), 186-200.

Widodo, A., \& Asas, I. (2017). Determinants of Islamic Rural Bank Financing in Indonesia. JEJAK: Jurnal Ekonomi dan Kebijakan, 10(2), 273-288.

Widyawati, S., \& Wahyudi, S. T. (2016). Determinan Pertumbuhan Kredit Modal Kerja Perbankan di Indonesia: Pendekatan Error Correction Model (ECM). Jurnal Keuangan dan Perbankan, 20(1), 149-156.

Yusuf, Y., Hubeis, M., \& Hardjomidjojo, H. (2010). Model Penyaluran Kredit Kepada Usaha Mikro dan Kecil Berdasarkan Karakter dan Kapasitas (Kasus Unit Kemitraan dan Bina Lingkungan PT. Sucofindo). Jurnal MPI, 1(2). 